\title{
Transnational Entrepreneurship
}

Eduardo Bailetti

\section{Source}

Eduardo Bailetti. (2018). Transnational Entrepreneurship: Distinctive Features and a New

Definition. TIM Review, vol. 8 (9), 28-38. doi:10.22215/timreview/1184.

A cross-border investment to acquire, combine, and recombine specialized individuals and heterogeneous assets to create and capture value for the company under conditions of institutional distance and uncertainty. 